\title{
Comparative Study on the Effect of C667T and A1298C Polymorphism in Preeclampsic Cases
}

\author{
Rizk Ahmed EL Baz**, Manal Mohamed Ramadan*, Eman Fayad***, Ali Ali Shaltot**, and \\ Effat Mahmoud EL Shershaby * \\ * Faculty of Science, Zoology department at Mansoura University. \\ ** Faculty of Medicine, Genetic department at Mansoura University. \\ *** Faculty of Science, Zoology department at Mansoura University, assistant professor at \\ Biotechnology department, Faculty of science at Taif University.
}

\begin{abstract}
:
Objective: To identify polymorphism of methylenetetrahydrofolate reductase gene in women suffering from preeclampsia.

Study design: From 142 pregnant women we identify 92 women suffer from preeclampsia and 50 healthy controls with normal pregnancy matched for age and socioeconomic status, preeclampsic patient classified as mild preeclampsia $42(45.7 \%)$ and severe preeclampsia 50(54.3\%). Blood samples were tested for DNA polymorphism affecting thrombophilia methylenetetrahydrofolate reductase C677T and A1298C.

Results: Homozygous TT genotype, $\mathrm{T}$ allele of C677T polymorphism has a significantly higher frequency among preeclampsic cases compared to healthy controls ( $\mathrm{OR}=21.7,1.46$, respectively). Thus TT genotype and T allele may be considered as genetic risk factors for preeclampsic cases. on the other hand, non significant association in either genotype among preeclampsic cases compared to controls regarding to A1298C.
\end{abstract}

Key words: C667T gene, A1298C, preeclampsia.

\section{Introduction:}

Preeclampsia defined as pregnancy-induced protein uric hypertension with onset of clinical symptoms beyond 20 weeks gestation, It is a serious pregnancy complication and a leading cause of maternal mortality and fetal perinatal morbidity. ${ }^{(1,2)}$

Clinically, disease may also be associated with abnormalities of the central nervous system, the liver, the kidneys, and intra-vascular disseminated coagulation.$^{(3,4,5)}$

The human methylenetetrahydrofolate reductase [MTHFR] gene, which is located on chromosome 1p36, belongs to the proposed candidate loci for preclampsia ( $^{(6)}$

The MTHFR gene is critical in the metabolism of homocysteine because the reaction catalyzed by MTHFR is a rate-limiting step in the folate cycle and can be affected by individual's folate status. . $(7,8)$

Polymorphisms have been identified in the gene encoding MTHFR. $(9,10,11)$ The two most common variants of the MTHFR gene are located at nucleotides 677 (C677T) and 1298 (A1298C) . $(9,12)$
Hyperhomocystinemia can induce vascular injury, increase platelet consumption, and can result in thrombosis caused by increased oxidative stress. Clinically, hyperhomocystinemia caused by the C677T and A1298C mutation has been implicated in premature cardiovascular disease ${ }^{(13)}$, Venous thrombosis.$^{(14)}$ and more recently in adverse pregnancy outcome, especially preeclampsia. $^{(15,6,16)}$

\section{Material and Methods:-}

This study was reviewed and approved by the Mansoura University of science, and informed consent was obtained from all the study groups.

\section{Study groups: \\ Group I (Patients):}

This group comprised 92 cases selected randomly from those attending Obstetrics and Gynecology Department at Mansoura University Hospitals, complaining of preeclampsia. They were collected through one year from August 2008. Age of the patients ranged from 20-28 years (mean age 23.91 \pm 2.1 years). They were classified into mild preeclampsia, 42 cases $(45.7 \%)$ and severe preeclampsia, 50 cases $(54.3 \%)$. 


\section{Group II (control group):}

This group included 50 healthy females, with normal pregnancy, matched for age, residency and socioeconomic status.

\section{Methods:}

DNA extraction:

The Generation DNA Purification Capture Column Kit is based on a proprietary system that uses two reagents, a DNA Purification Solution (Solution 1) and a DNA Elution Solution (Solution 2) along with a specially formulated purification matrix.

\section{Polymerase chain reaction:}

PCR is based on the enzymatic amplification of a fragment of DNA that is flanked by two primers (short oligonucleotide) that hybridize to the opposite strands of the target sequence and primer extention according to the complementary sequence by using enzyme DNA polymerase. Hybridization of the primers and enzymatic DNA synthesis result in an exponential amplification $(2,4,8,16,32 \ldots$ copies).

\section{PCR amplifications:}

We genotyped two single nucleotide polymorphisms (SNPs) for methylenetetrahydrofolate reductase gene (MTHFR) in this case-control study; C677T and A1298C polymorphisms using polymerase chain reaction with sequence-specific primers (SSPPCR).

Primer sequences, PCR conditions and digestion of each polymorphism studied:

\section{MTHFR C677T polymorphism ${ }^{(17)}$ :}

For evaluation of MTHFR C677T polymorphism, the polymorphic site was amplified with primers:

Forward (5-TGA AGG AGA AGG TGT CTG CGG GA- 3`) and

Reverse (5-AGG ACG GTG CGG TGA GAG TG- 3`) (Gibeo BRL).

For PCR the following procedure was used: preliminary denaturation at $95 \mathrm{C}$ for $3 \mathrm{~min}$, 5 cycles: denaturation at $94 \mathrm{C}$ for $1 \mathrm{~min}$, annealing at $64 \mathrm{C}$ for $1 \mathrm{~min}$, synthesis at $72 \mathrm{C}$ for $30 \mathrm{sec}$, next 30 cycles were run: denaturation at $94 \mathrm{C}$ for $45 \mathrm{sec}$, annealing at $62 \mathrm{C}$ for $45 \mathrm{sec}$, synthesis at $72 \mathrm{C}$ for $25 \mathrm{sec}$ and final synthesis at $72 \mathrm{C}$ for $7 \mathrm{~min}$. Digestion was performed by restrictase HinfI (Fermentas) at $37 \mathrm{C}$ for $4 \mathrm{~h}$.

\section{MTHFR A1298C polypmorphism ${ }^{(17)}$ :}

For evaluation of MTHFR A1298C polymorphism, the following primers were used: Forward (5 - CTT TGG GGA GGT GAA GGA CTA CTA C- $\left.3^{\prime}\right)$ and

\section{Reverse (5 - CAC TTT GTG AGC ATT CCG} GTT TG- 3') (Gibeo BRL).

The PCR procedure was composed of preliminary denaturation at $95 \mathrm{C}$ for $2 \mathrm{~min}, 5$ cycles: denaturation at $95 \mathrm{C}$ for $1 \mathrm{~min}$, annealing at $55 \mathrm{C}$ for $2 \mathrm{~min}$, synthesis at $72 \mathrm{C}$ for $2 \mathrm{~min}$, next 32 cycles were run: denaturation at $95 \mathrm{C}$ for $75 \mathrm{sec}$, annealing at $55 \mathrm{C}$ for $75 \mathrm{sec}$, synthesis at $72 \mathrm{C}$ for $90 \mathrm{sec}$ and final synthesis at $72 \mathrm{C}$ for 6 min. the PCR was carried out with a thermal cycler UNO II (Biometra). Restrictase MboII was used for digestion at $37 \mathrm{C}$ for $7 \mathrm{~h}$.

The C677T mutation introduces a new HinfI restriction site which results in the digestion of the $198 \mathrm{bp}$ amplicon into 175 and $23 \mathrm{bp}$ fragments. By abolishing an MboII restriction site, the A1298C mutation results in the digestion of the $163 \mathrm{bp}$ amplicon into $84,31,30$, and $18 \mathrm{bp}$ fragments.$^{(18)}$ The wild-type 1298AA yields five fragments, and the 84-bp fragment is cut into 56- and 28-bp fragments producing base pair lengths of 56, 31, 30, 28 and $18 .{ }^{(19)}$

\section{Detection of amplified digested products: Mini Gel Electrophoresis:}

Agarose gel electrophoresis is used to resolve DNA fragments according to their molecular weight where smaller fragments migrate faster than larger ones.

\section{Statistical analysis:}

All data were collected and tabulated and statistically analyzed using SPSS statistical computer package version 10 software. Quantitative variable were expressed as mean \pm $\mathrm{SD}$, while the qualitative variables were presented as numbers and percents. Comparison of qualitative data was done using Fisher's Exact test. Odds ratio (OR) and $95 \%$ confidence interval $(95 \% \mathrm{CI})$ were also used to compare the frequency among study and control groups to assess risk factors. Statistical significance was set at $\mathrm{P}<0.05$. 


\section{Results}

Table (1): Descriptive data of preeclampsic cases

\begin{tabular}{||ll||}
\hline \hline & Cases \\
\hline \hline Number & 92 \\
Age (Years) & \\
Mean \pm SD & $23.91 \pm 2.1$ \\
Median & 24.00 \\
Range & $20.00-28.00$ \\
Diagnosis & \\
Mild Preeclampsia & $42(45.7 \%)$ \\
Sever preeclampsia & $50(54.3 \%)$ \\
Parity & \\
Primigravida & $51(55.4 \%)$ \\
Multigravida & $41(44.6 \%)$ \\
Family history (positive/negative) & $42 / 50$ \\
Systolic blood pressure & \\
140 - 160 & $62(67.4 \%)$ \\
$>160$ & $30(32.6 \%)$ \\
Diastolic blood pressure & \\
90 - 110 & $32(34.8 \%)$ \\
$>110$ & $60(65.2 \%)$ \\
Gestational age & \\
$\quad \leq 36$ week & $66(71.7 \%)$ \\
$>36$ week & $26(28.3 \%)$ \\
\hline
\end{tabular}

Table (2): Comparison between preeclampsic cases and controls regarding their allele frequency and genotype distribution of C677T and A1298C polymorphisms of MTHFR gene.

\begin{tabular}{|c|c|c|c|c|c|}
\hline \multirow[b]{2}{*}{ C677T } & \multicolumn{3}{|c|}{ Genotypes } & \multicolumn{2}{|c|}{ Alleles } \\
\hline & $\begin{array}{c}\mathrm{CC} \\
\mathrm{n}(\%)\end{array}$ & $\begin{array}{c}\mathrm{CT} \\
\mathrm{n}(\%)\end{array}$ & $\begin{array}{c}\mathrm{TT} \\
\mathrm{n}(\%)\end{array}$ & $\begin{array}{c}\mathrm{C} \\
\mathrm{n}(\%)\end{array}$ & $\begin{array}{c}\mathrm{T} \\
\mathrm{n}(\%)\end{array}$ \\
\hline $\begin{array}{c}\text { Cases } \\
(\mathrm{n}=92)\end{array}$ & $39(42.4 \%)$ & $37(40.2 \%)$ & $16(14.4 \%)$ & $115(62.5 \%)$ & $69(37.5 \%)$ \\
\hline $\begin{array}{l}\text { Controls } \\
(n=50)\end{array}$ & $21(42.0 \%)$ & $29(58.0 \%)$ & $0(0.0 \%)$ & $71(71.0 \%)$ & $29(29.0 \%)$ \\
\hline $\mathrm{P}$ & 1.0 & 0.05 & $0.0007 * *$ & 0.19 & 0.19 \\
\hline \multirow[t]{2}{*}{ OR $(95 \% \mathrm{CI})$} & $1.0(0.50-2.0)$ & $0.48(0.24-0.98)$ & $21.7(1.27-371.5)$ & $0.68(0.40-1.15)$ & $1.46(0.86-2.48)$ \\
\hline & \multicolumn{3}{|c|}{ Genotypes } & \multicolumn{2}{|c|}{ Alleles } \\
\hline A1298C & $\begin{array}{c}\mathrm{AA} \\
\mathrm{n}(\%)\end{array}$ & $\begin{array}{c}\mathrm{AC} \\
\mathrm{n}(\%)\end{array}$ & $\begin{array}{c}\mathrm{CC} \\
\mathrm{n}(\%)\end{array}$ & $\begin{array}{c}\mathrm{A} \\
\mathrm{n}(\%)\end{array}$ & $\begin{array}{c}\mathrm{C} \\
\mathrm{n}(\%)\end{array}$ \\
\hline $\begin{array}{c}\text { Cases } \\
(\mathrm{n}=92)\end{array}$ & $33(35.9 \%)$ & $56(60.9 \%)$ & $3(3.3 \%)$ & $122(66.3 \%)$ & $62(33.7 \%)$ \\
\hline $\begin{array}{c}\text { Controls } \\
(n=50)\end{array}$ & $14(28.0 \%)$ & $36(72.0 \%)$ & $0(0.0 \%)$ & $64(64.0 \%)$ & $36(36.0 \%)$ \\
\hline $\mathrm{P}$ & 0.35 & 0.20 & 0.55 & 0.69 & 0.69 \\
\hline OR $(95 \% \mathrm{CI})$ & $1.34(0.64-3.04)$ & $0.60(0.28-1.27)$ & $3.95(0.19-78.06)$ & $1.10(0.66-1.84)$ & $0.90(0.54-1.50)$ \\
\hline
\end{tabular}

$\mathrm{n}=$ number of cases, $(\%)=$ percentage of cases, $\mathrm{OR}(95 \% \mathrm{CI})=$ Odds ratio and $95 \%$ confidence interval., Significance using Fisher's Exact Test: **p<0.05(highly significant). 


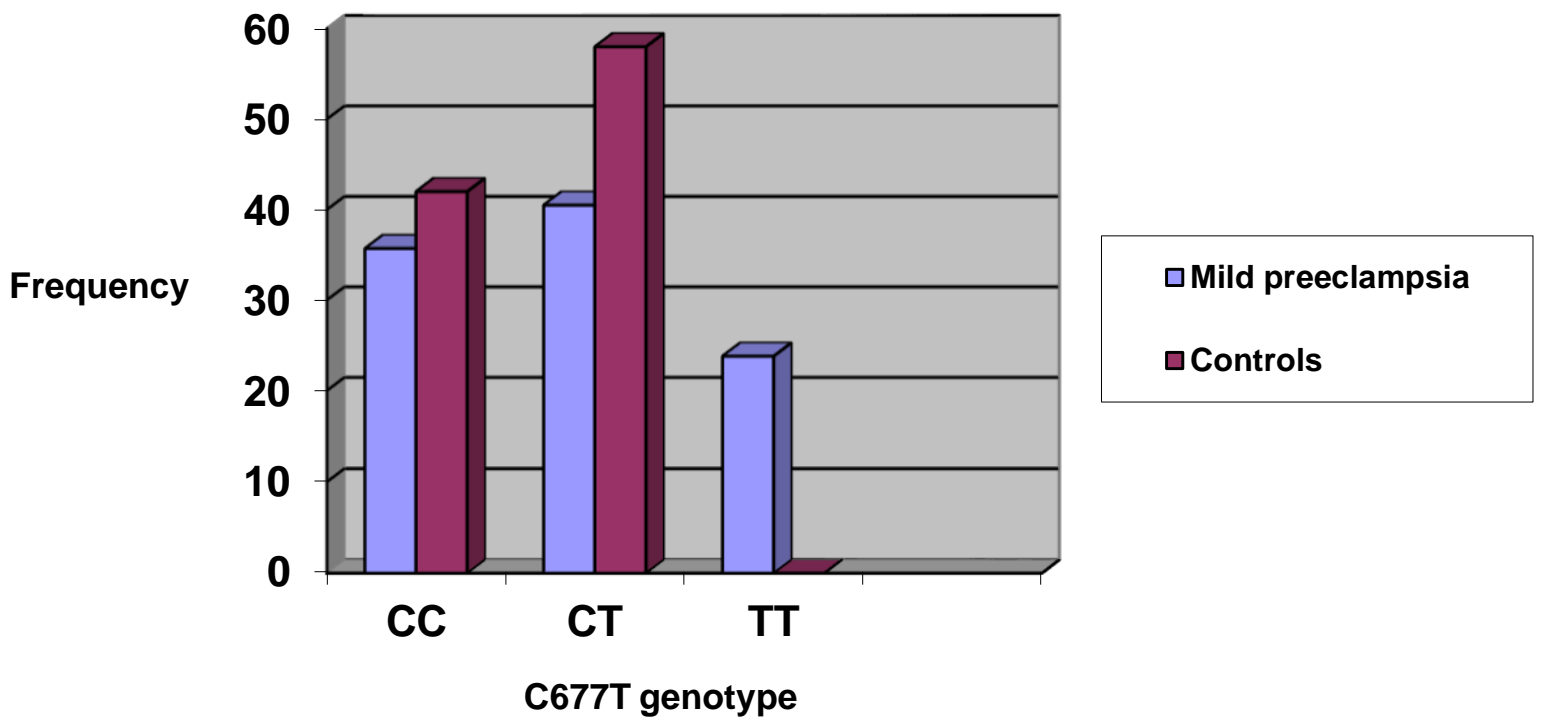

Fig. (1): Comparsion between genotype allele in Mild preeclampsic cases and healthy controls regarding their distribution and frequency of C677T polymorphism of MTHFR gene.

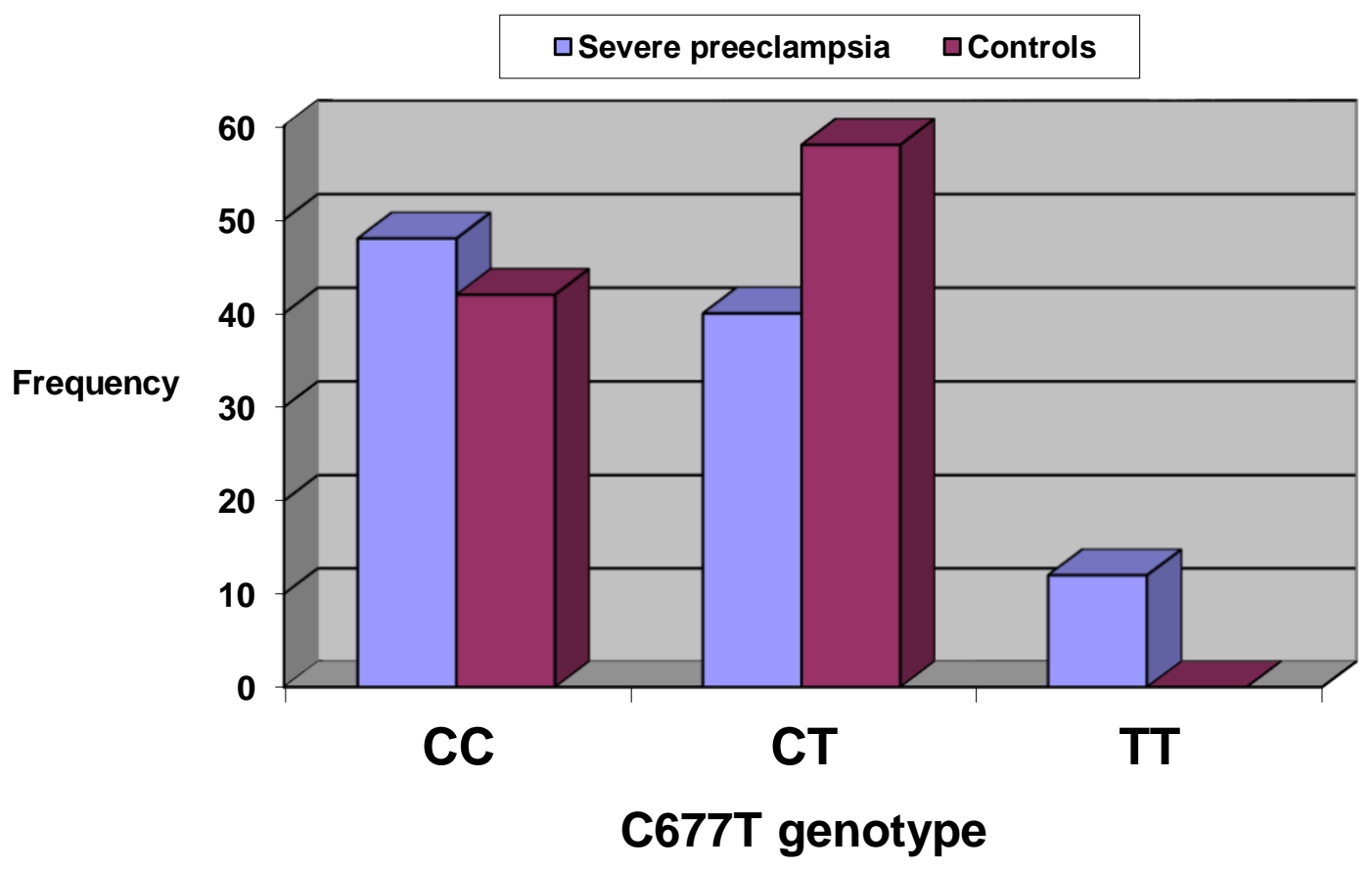

Fig. (2): Comparsion between genotype allele in sever preeclampsic cases and healthy controls regarding their distribution and frequency of C677T polymorphism of MTHFR gene. 


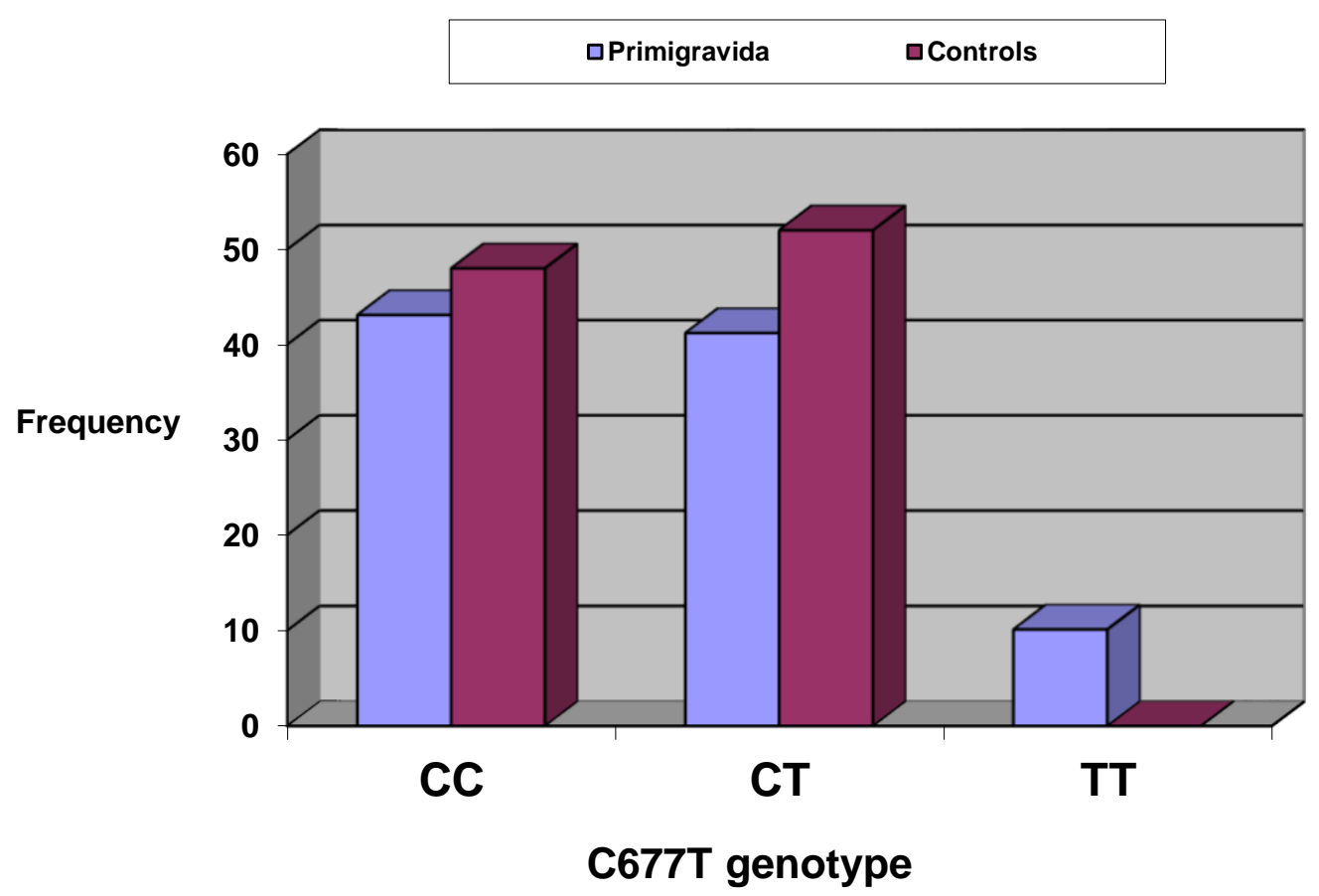

Fig. (3): Comparsion between genotypes alleles in primigravida regarding to C677T polymorphism of MTHFR gene.

'Table (3): Comparsion between C677T genotypes in relation to systolic blood pressure.

\begin{tabular}{|c|c|c|c|}
\hline \multirow[b]{2}{*}{ C677T } & \multicolumn{3}{|c|}{ Genotypes } \\
\hline & $\begin{array}{c}\mathbf{C C} \\
\mathbf{n}(\%)\end{array}$ & $\begin{array}{c}\text { CT } \\
\mathbf{n}(\%)\end{array}$ & $\begin{array}{c}\text { TT } \\
\mathbf{n}(\%)\end{array}$ \\
\hline $\begin{array}{c}\text { Systolic } \\
\text { blood pressure } \\
(140-160) \\
(n=62)\end{array}$ & $27(43.5 \%)$ & $23(37.1 \%)$ & $12(19.4 \%)$ \\
\hline $\begin{array}{c}\text { Controls } \\
(\mathbf{n}=\mathbf{5 0})\end{array}$ & $21(42.0 \%)$ & $29(58.0 \%)$ & $0(0.0 \%)$ \\
\hline $\mathbf{P}$ & 1.0 & 0.03* & $0.0005 * *$ \\
\hline $\begin{array}{c}\text { Systolic } \\
\text { blood pressure } \\
(>160) \\
(\mathbf{n}=\mathbf{3 0})\end{array}$ & $12(40.0 \%)$ & $14(46.7 \%)$ & $4(13.3 \%)$ \\
\hline $\begin{array}{c}\begin{array}{c}\text { Controls } \\
(\mathbf{n}=\mathbf{5 0}) \\
\mathbf{P}\end{array} \\
\end{array}$ & $\begin{array}{c}21(42.0 \%) \\
1.0 \\
\end{array}$ & $\begin{array}{c}29(58.0 \%) \\
0.36 \\
\end{array}$ & $\begin{array}{c}0(0.0 \%) \\
\mathbf{0 . 0 1} *\end{array}$ \\
\hline
\end{tabular}

$\mathrm{n}=$ number of cases; $(\%)=$ percentage of cases significance. Significance using Fisher's Exact Test $* \mathrm{p}<0.05$ (significant); **p $<0.05$ (highly significant). 


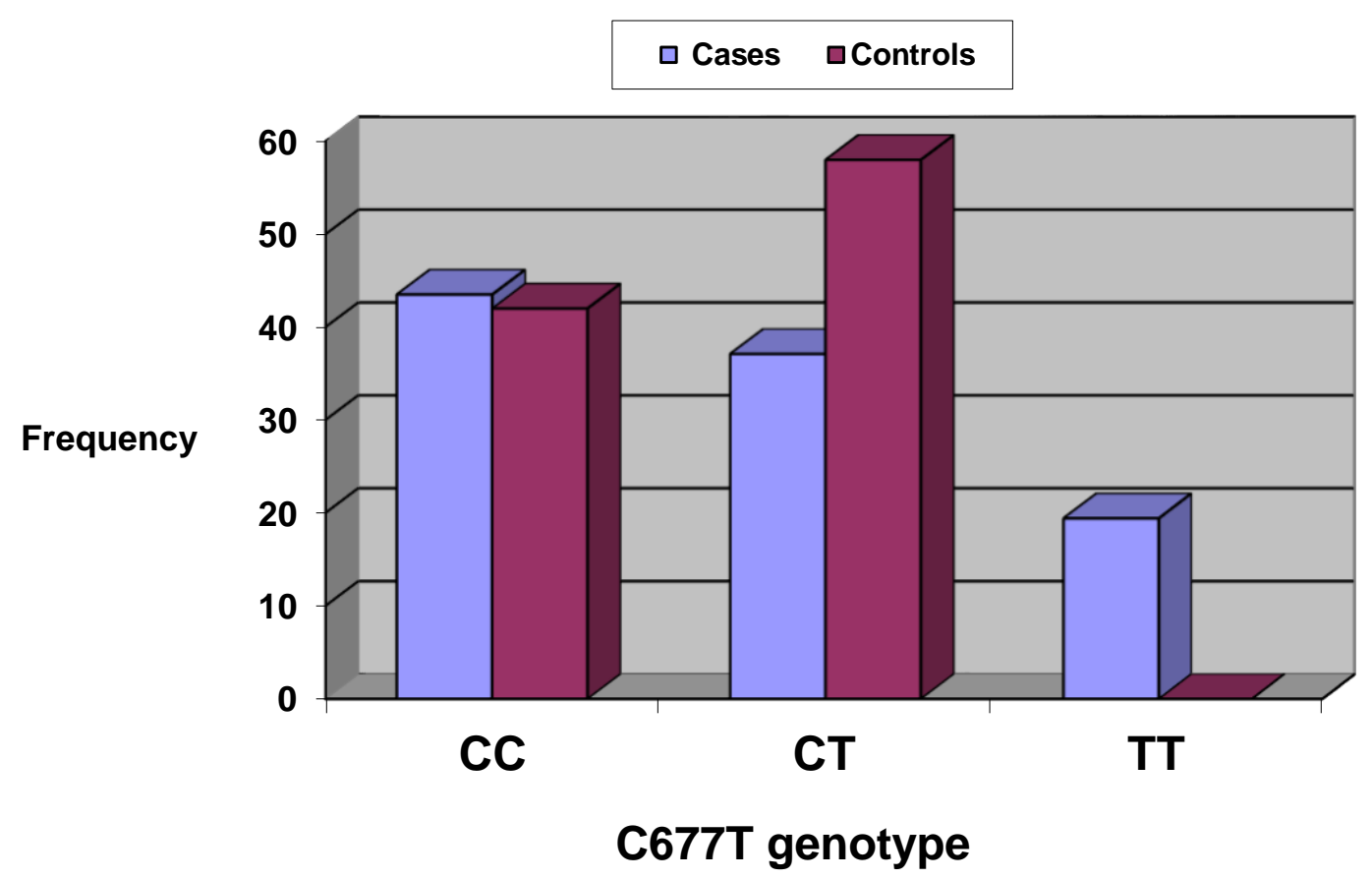

Fig. (4): Comparsion between genotype alleles in relation to diastolic blood pressure (90-110) regarding to C677T polymorphism.

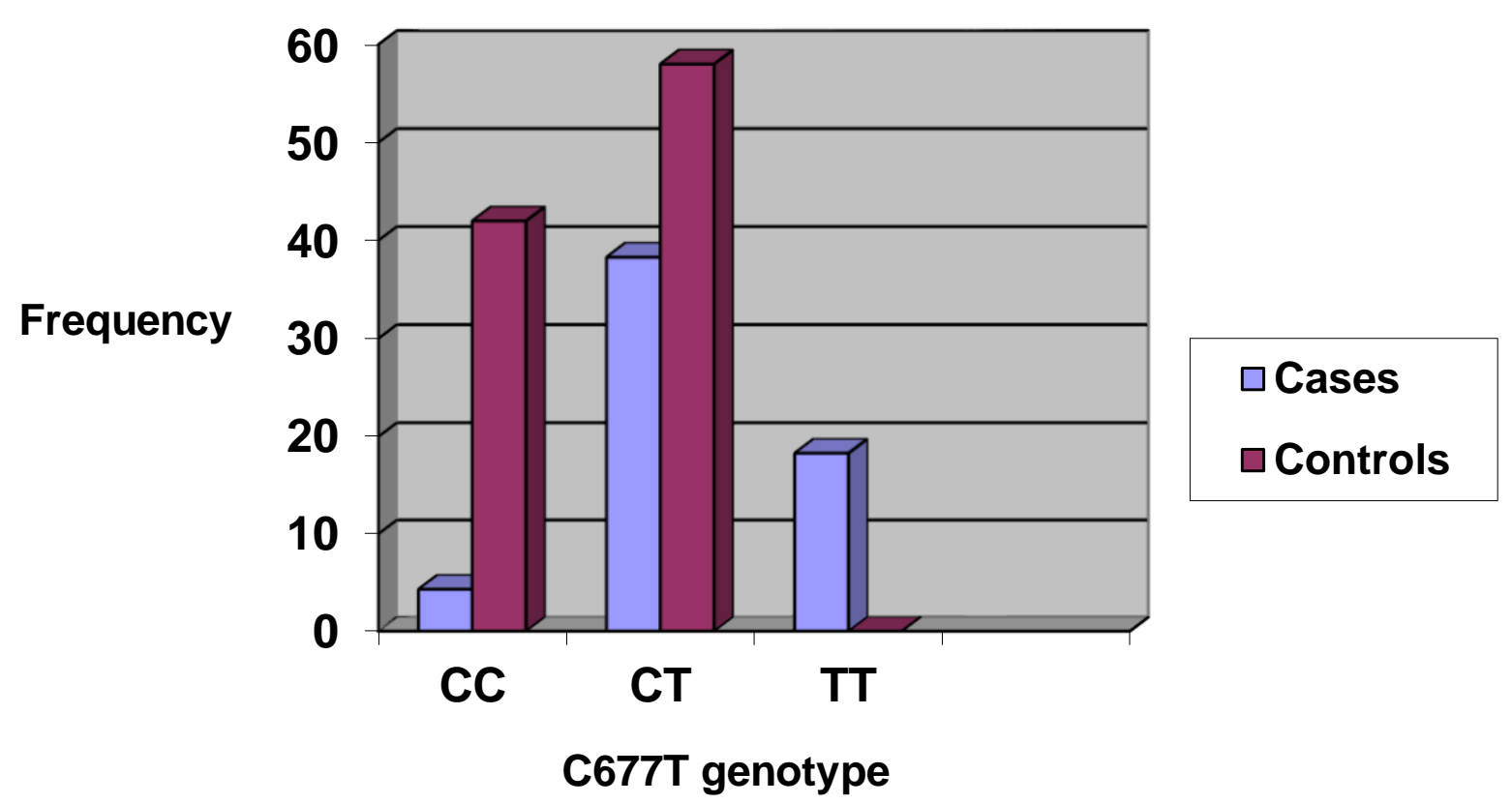

Fig. (5): Comparsion between genotype alleles in relation to diastolic blood pressure $(>110)$ regarding to C677T polymorphism. 
Table (4): Comparsion between cases and healthy controls in relation to C677T polymorphism regarding to age.

\begin{tabular}{|c|c|c|c|}
\hline Age & & notypes & \\
\hline$\leq 24$ years & $\begin{array}{c}\mathbf{C C} \\
\mathbf{n}(\%)\end{array}$ & $\begin{array}{c}\mathbf{C T} \\
\mathbf{n}(\%)\end{array}$ & $\begin{array}{c}\text { TT } \\
\mathbf{n}(\%)\end{array}$ \\
\hline $\begin{array}{l}\text { Cases } \\
(n=54)\end{array}$ & $21(38.9 \%)$ & $22(40.7 \%)$ & $11(20.4 \%)$ \\
\hline $\begin{array}{l}\text { H. controls } \\
\quad(n=31)\end{array}$ & $10(32.3 \%)$ & $21(67.7 \%)$ & $0(0.0 \%)$ \\
\hline $\mathbf{P}$ & 0.64 & $0.02 *$ & $0.006 *$ \\
\hline \multicolumn{4}{|l|}{$>24$ years } \\
\hline $\begin{array}{c}\text { cases } \\
(n=38)\end{array}$ & $18(47.4 \%)$ & $15(39.5 \%)$ & $5(13.1 \%)$ \\
\hline $\begin{array}{l}\text { H. controls } \\
(n=19)\end{array}$ & $11(57.9 \%)$ & $8(42.1 \%)$ & $0(0.0 \%)$ \\
\hline $\mathbf{P}$ & 0.57 & 1.0 & 0.15 \\
\hline
\end{tabular}

$\mathrm{n}=$ number of cases; $(\%)=$ percentage of cases significance. Significance using Fisher's Exact Test $* \mathrm{p}<0.05$ (significant), $* \mathrm{p}<0.05$ (highly significant). 


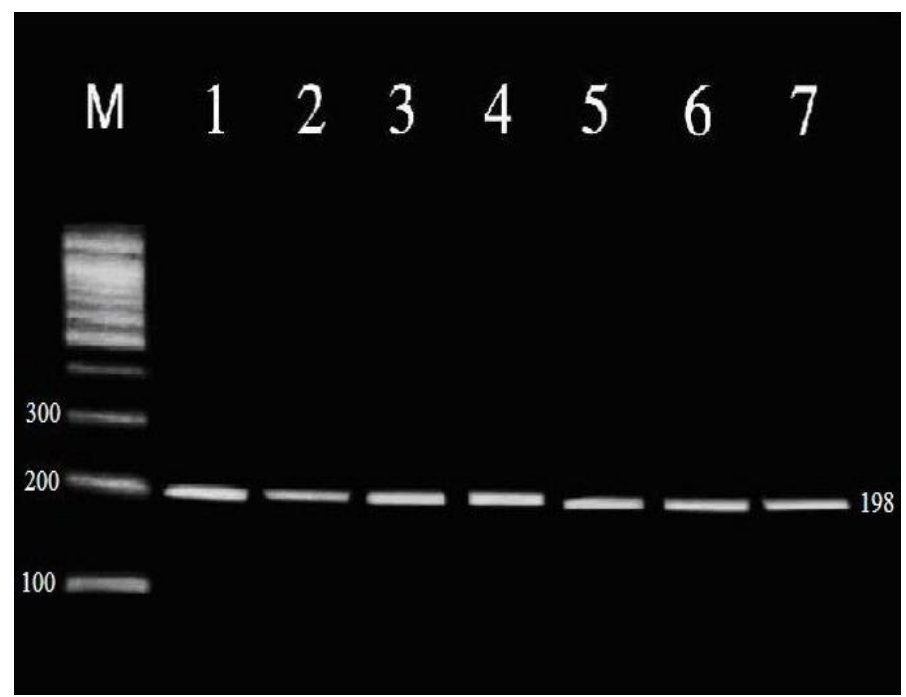

Fig (6): PCR amplification of C677T polymorphism of MTHFR gene. lane M: DNA marker size (100 bp) and 1-7: PCR product of C677T polymorphism have band size $198 \mathrm{bp}$.

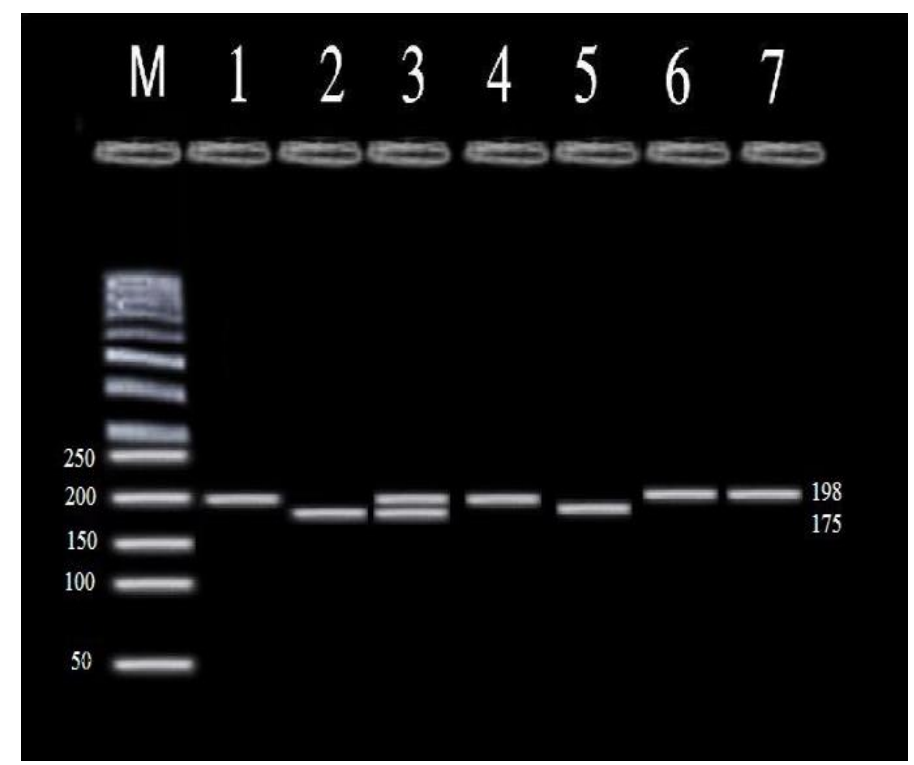

Fig (7): Enzymatic digestion of C677T polymorphism of MTHFR gene. Digestion of PCR product of C677T polymorphism of MTHFR gene using HinfI enzyme. which digests the 198- bp fragment into 175- and 23- bp fragments; the small 23- bp fragment has run off the gel. Lane M: DNA size marker (50 bp), lane 1,4,6 and 7 (wild type CC is found which appears at $198 \mathrm{bp}$ ), lane 3 (heterozygous mutated genotype CT which has 198, 175, 23 bp fragments) and lane 2 and 5 (homozygous mutated genotype TT is found which has 175, $23 \mathrm{bp}$ fragments). 


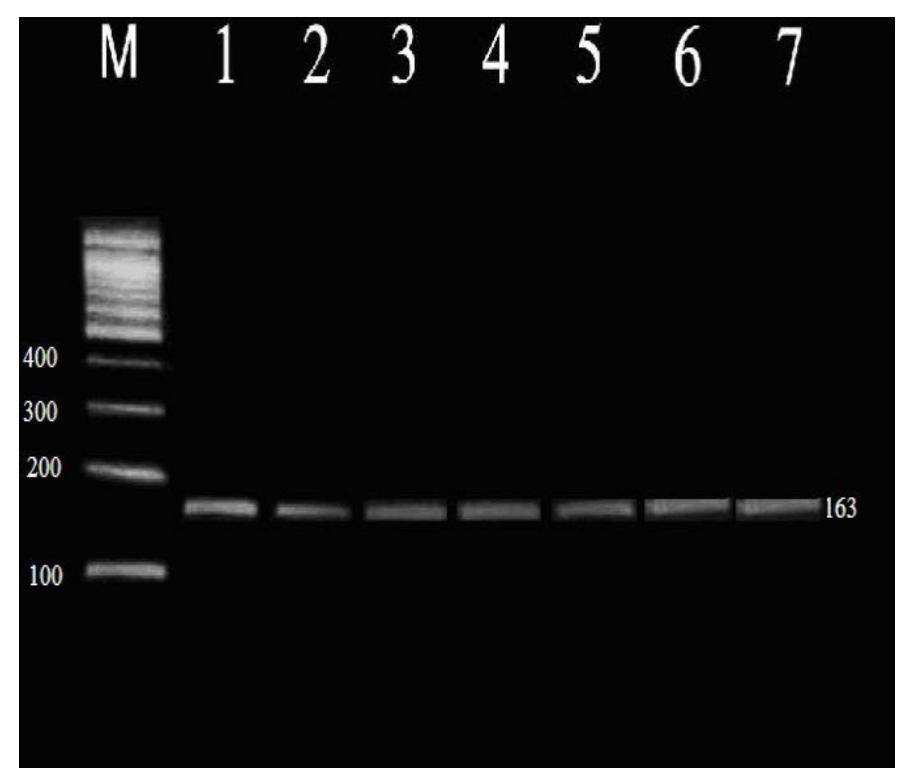

Fig (8): PCR amplification of A1298C polymorphism of MTHFR gene. lane M (DNA size marker: $100 \mathrm{bp}$ ), lane 1-6 (PCR product of A1298C have band size: $163 \mathrm{bp}$ ), lane 7 (-ve control).

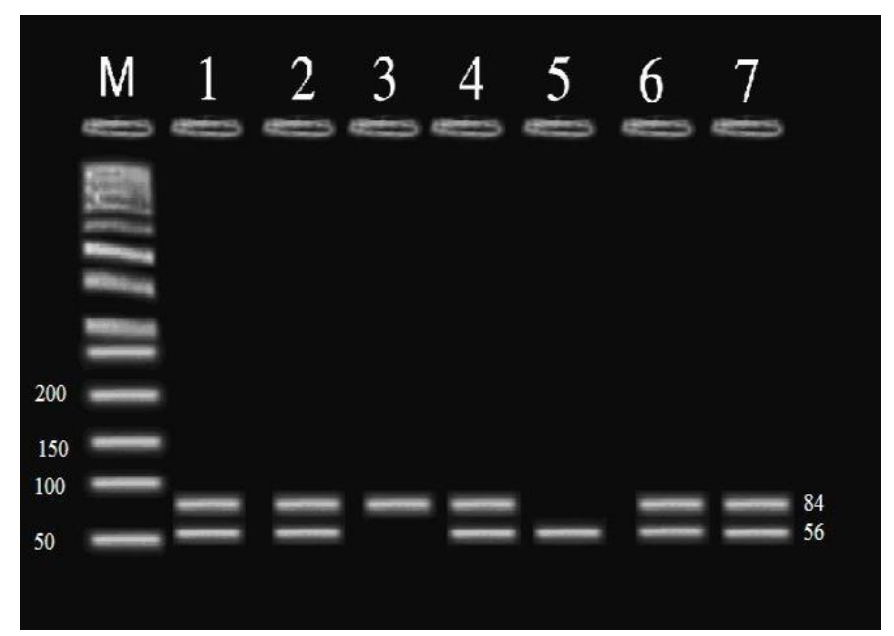

Fig (9): Enzymatic digestion of A1298C polymorphism of MTHFR gene. Digestion of PCR product of A1298C polymorphism of MTHFR gene using MobII enzyme which digests the $163 \mathrm{bp}$ fragment of the mutated type CC into 84, 31, 30, and $18 \mathrm{bp}$ fragments, while The wild-type AA yields five fragments 56, 31, 30, 28 and 18 ; the small 18, 28, 30, $31 \mathrm{bp}$ fragments have run off the gel. Lane M : DNA size marker (50 bp), Lane 5 (wild type AA), lane $1,2,4,6$, and 7 (heterozygous mutated type $\mathrm{AC}$ which has 84, 56, 31, 30, 28 and 18 bp fragments) and lane 3 (homozygous mutated genotype $\mathrm{CC}$ fragments). 


\section{Discussion:-}

Preeclampsia is a common pregnancyrelated hypertension syndrome that poses a major risk of mortality and morbidity on both the woman and fetus. ${ }^{(20)}$ It has been appreciated for almost 4 decades that it has a familial basis, although the exact mode of inheritance remains unclear .(21) The pathophysiology of preeclampsia reflects widespread dysfunction of the maternal vascular endothelium ${ }^{(22)}$, and vascular

diseases such as diabetes, essential hypertension, and antiphospholipid syndrome predispose pregnant women to preeclampsia. This, together with the marked thrombotic tendency of some women with preeclampsia (23) , has suggested a number of candidate genes that may be involved in the pathophysiology of preeclampsia. ${ }^{(24)}$

Methylenetetrahydrofolate reductase (MTHFR) is a key regulatory enzyme in folate and homocysteine metabolism it catalyzes the reducation of 5,10-methylenetetrahydrofolate to 5-methyltetrahydrofolate, thus generating the active form of folate required for methylation of homocysteine to methionine. Deficiency of MTHFR may be associated with an increase in plasma homocysteine, which in turn is associated with an increased risk of vascular disease. ${ }^{(8)}$

It include two variants C677T and A1298C (25) The C677T alters the protein's folate binding site and lowers the enzymatic activity of MTHFR. The A1298C variant also decreases the enzymatic activity of MTHFR, which is more pronounced in homozygous variant than in heterozygous state. ${ }^{(26)}$

The current study was done to identify polymorphism of methylenetetrahydrofolate reductase gene and compare between these polymorphic changes and other factors associated with preeclampsia and the implication of associated genotypes as risk factors for the development of preeclampsia.

Data showed that homozygous TT genotype, mutant $\mathrm{T}$ allele of C677T polymorphism has a significantly higher frequency among preeclampsic cases compared to healthy controls $(\mathrm{OR}=21.7,1.46$, respectively). Thus TT genotype and $\mathrm{T}$ allele may be considered as genetic risk factors for preeclampsic cases. On the other hand, significant lower frequency of wild CC genotype and $\mathrm{C}$ allele of C677T polymorphism was observed among preeclampsic cases $(\mathrm{OR}=1.0,0.68$, respectively). So, CC genotype may be considered as a protective factor against the development of preeclampsia.

These findings are in agreement with results of ${ }^{(27,28)}$, who reported that risk of pregnancy failure was significantly elevated in carriers of the homozygous variant of SNPs 677T/T, they also reported the association of MTHFR 677T/T with idiopathic RPL.

Unfrid $\boldsymbol{e t}$ al. ${ }^{(29)}$ reported that polymorphism of MTHFR gene is associated with idiopathic recurrent miscarriage in a Middle - European white population, they found that homozygosity for MTHFR C677T polymorphism confers a 3.7- fold increased risk of idiopathic recurrent miscarriage (OR $3.7,95 \%$ CI $1.2,11.8)$.

Nelen et al. ${ }^{(30)}$ reported an increased prevalence of the C677T mutation in a cohort of Dutch women with a history of unexplained recurrent pregnancy loss. They found a threefold increased risk (OR 3.3, 95\% CI 1.3, 10.1) for recurrent miscarriage in women homozygous for MTHFR T/T genotype (genotype frequencies: $16 \%$ in the study group, $5 \%$ in the control group).

On the other hand, Gerhardt et al. ${ }^{(31)}$, found no significant risk association of the methylenetetrahydrofolate reductase 677TT genotype with severe preeclampsia, (OR 0.8, $95 \%$ CI 0.4, 1.8).Also, Stamatian et al. . ${ }^{(32)}$ reported that, MTHFR C677T occurred more frequently in the control group (38.4\%) than in the studied group $(36.1 \%)(\mathrm{P}=0.8)$.

Regarding genotypes and alleles of A1298C polymorphism in the present study no significant differences in the frequencies of genotypes and alleles among preeclampsic cases compared to healthy controls were observed. The association of the C677T with preeclampsic cases may be more significant than $\mathrm{A} 1298 \mathrm{C}$ due to the localization of these two mutations. The C677T mutation, found in exon 4, lies within the MTHFR catalytic domain, while the A1298Cmutation, found in exon 7 , is located within the enzyme regulatory domain..$^{(18)}$

Nelen et al. ${ }^{(27)}$ and Lissak et al. ${ }^{(28)}$, reported that the risk of pregnancy failure was significantly elevated only in carriers of the homozygous variant of both SNPs 1298 C/C. MTHFR A1298C SNPs were implicated in 
several pregnancy-related complications, including placental anomalies . ${ }^{(33)}$, preeclampsia.$^{(34,35)}$ and RPL. ${ }^{(30,36,37)}$

Stamatian et al. (32), investigate the relationship between the presence of specific genetic mutations and the occurrence of complications in the first trimester of pregnancy, they found that MTHFR A1298C mutation was more frequently isolated in the studied group (52.7\%) as compared with the control group $(46.1 \%)(\mathrm{P}=0.5)$.

Said et al. ${ }^{(38)}$ estimate association between five commonly inherited thrombophilia polymorphisms and adverse pregnancy outcomes, they found that homozygous carriers of the MTHFR 1298 polymorphism had an odds ratio of 0.26 , (95\% CI 0.08-0.086, $\mathrm{P}=0.03$ ) and they concluded that homozygosity for MTHFR 1298 may protect against pregnancy complications.

The present data showed that homozygous mutated TT genotype had significantly higher frequency among both mild and severe preeclampsic cases $(\mathrm{P}=0.0002, \quad 0.02$, respectively), in relation to the controls. On other hand, no significant higher frequency in genotypes of $\mathrm{A} 1298 \mathrm{C}$ polymorphism $(\mathrm{P}>0.05)$ in either mild or severe cases compared with healthy controls.

As regards genotype polymorphism in relation to parity, our study revealed only significant high frequency in homozygous mutated 677/TT ( $\mathrm{P}=0.04,0.32$, respectively) in primigravida compared with the controls but no significant difference in other genotypes of C677T or A1298C polymorphism between primigravida and multigravida $(\mathrm{P}>0.05)$.

Sacchi et al. (39) , found that the allele frequency of MTHFR C677T and A1298C SNPs among control primigravida women was similar to that of healthy Tunisians, thereby ruling out probability bias in control selection, and was comparable with rates established for European and Mediterranean .(40) communities. In view of their presence among control women, and as not all MTHFR C677T and A1298C mutant genotype carriers experienced RPLs, this indicated that the concerted participation of multiple inherited and non-inherited prothrombotic defects placed women at greatest risk.

The present data showed no significant difference in frequency in either genotype of C677T or A1298C polymorphism in relation to positive family history of preeclampsic cases or gestational age ( $\leq 36$ weeks or $>36$ weeks) of preeclampsic cases.

Nelen et al. ${ }^{(30)}$ and Lissak et al. ${ }^{(28)}$, found that pregnancy losses were categorized into early (5-12 weeks), late (13-30 weeks) and combined early-late. The risk of pregnancy failure was significantly elevated only in carriers of the homozygous variant of both SNPs $(677 \mathrm{~T} / \mathrm{T}$ and $1298 \mathrm{C} / \mathrm{C})$ and, interestingly, was seen in patients experiencing late (C677T) and combined early-late (C677T and A1298C), but not exclusively early miscarriages. This was in accord with earlier studies, which reported on the association of MTHFR 677T/T ( acting through elevation of tHcy) with idiopathic RPL, more so with late than for first trimester abortions . ${ }^{(41)}$

The present study revealed a significant high frequency of homozygous mutant 677/TT in relation to high systolic $(\mathrm{P}=0.0005,0.01$, respectively) and diastolic blood pressure ( $\mathrm{P}=0.03,0.36$, respectively). On the other hand, other genotypes of C677T and all genotypes of A1298C polymorphism have no significant association with high systolic or diastolic blood pressure. So, 677/TT genotype in preeclampsic patients may be a genetic risk marker for the development of severe hypertension or severe preeclampsia.

The present data showed significant high frequency of homozygous mutant 677/TT $(\mathrm{P}=0.006)$ in relation to younger age of preeclampsic patients ( $\leq 24$ years), while other genotypes of both C677T and A1298C polymorphism have no significant relation to the age. Studies are providing conflicting data on this point, however Zhang . ${ }^{(42)}$, reported that increasing maternal age raises risk.

\section{From the previous results, we can conclude that:}

1- Thrombophilic gene mutations of MTHFR (homozygous 677/TT) associated with development of preeclampsia.

2- Wild genotypes of MTHFR gene (C677C) and Prothrombin gene may be considered protective factors against preeclampsia.

3- 677/TT genotype may be genetic risk markers for severe hypertension or predictors of severe preeclampsia.

4- Combination of thrombophilic gene mutations (MTHFR) raise the risk of preeclampsia than single thrombophilic defect. 


\section{Reference:-}

1-Chesley LC (1984): History and epidemiology of preclampsia-eclampsia. Clin. Obstet. Gynecol., 27: 801-820.

2- Kaunitz AM, Hughes JM, Grimes DA, Smith JC, Rochat RW, Kafrissen ME (1985): Causes of maternal mortality in the United States. Obstet Gynecol., 65: 605-612.

3- Sibai BM (1990): Medical disorders in pregnancy, including hypertensive diseases. Curr.Opin. Obstet. Gynecol., 2: 13-22.

4- Kenny L, Baker PN (1999): Maternal pathophysiology in preclampsia. Baillieres Best Pract. Res. Clin. Obstet. Gynaecol., 13: 59-75.

5- Rath W, Faridi A, Dudenhausen JW (2000): HELLP syndrome. J. Perinat., Med. 28: 249-260.

6- $\quad$ Sohda S, Arinami T, Hamada $H$, Yamada N, Hamaguchi H, Kubo T (1997): Methylenetetrahydrofolate reductase polymorphism and preclampsia. J. Med. Genet., 34: 525-526.

7- Powers RW, Minich LA, Lykins DL, Ness RB, Crombleholme WR, Roberts JM(1999): Methylenetetrahydrofolate reductase polymorphism, folate, and susceptibility to preclampsia. J. Soc. Gynecol. Investig., 6: 74-79.

8- Fodinger M, Horl WH, SunderPlassmann G (2000): Molecular biology of 5,10methylenetetrahydrofolate reductase. J. Nephrol., 13: 20-33.

9- $\quad$ Frosst P, Blom HJ, Milos R, Goyette P, Sheppard CA, Matthews RG, Boers GJ, den Heijer M, Kluijtmans LA, van den Heuvel LP et al. (1995): A candidate genetic risk factor for vascular disease: a common mutation in methylenetetrahydrofolate reductase. Nat Genet., May;10(1):111-113.

10- Goyette P, Frosst P, Rosenblatt Ds, Rozen $\boldsymbol{R}$ (1995): Seven novel mutations in the methylenetetrahydrofolate reductase gene and genotype/phenotype correlations. Am J Hum Genet., 56: 1052-1059.

11- Kluijtmans LA, Wendel U, Stenvens EM, Van den Heuvel LP, Trijbels FJ,Blom HJ (1998): Identification of four novel mutations in severe methylenetetrahydrofolate reductase deficiency. Eur J Hum Genet., 6: 257-265.

12-Weisberg I, Tran P, Christensen B, Sibani S, Rozen $R$ (1998): A second genetic polymorphism in methylenetetrahydrofolate reductase (MTHFR) associated with decreased enzyme activity.Mol Genet Metab., Jul;64(3):169-172.

13- Kluijtmans LA, Kastelein JJP, Lindemans J, Boers GHJ, Heil SG, Bruschke AVG (1997): $\quad$ Thermolabile methylenetetrahydrofolate reductase in coronary artery disease. Circulation, 96: 2573-2577.
14- Markis .(2000):Hyperhomocysteinemia and thrombosis. Clin. Lab. Haematol., 22: 133143.

15- Grandone E, Margaglione M, Colaizzo D, Cappucci G, Paladini D, Martinelli P, Mantanaro S, Pavone G, Di Minno G(1997): Factor V Leiden, C $>$ T MTHFR polymorphism and genetic susceptibility to preclampsia. Thromb Haemost., 77: 1052-1054.

16- Kupferminc MJ, Eldor A, Steinman N, Many A, Bar-Am A, Jaffa A, Fait G, Lessing JB (1999): Increased frequency of genetic thrombophilia in women with complications of pregnancy. N. Engl. J. Med., 340: 9-13.

17- $\quad$ Siemianowicz K, Gminski J, Garczorz W, Slabiak N, Goss M, Machalski M, Magiera-Molendowska H.(2003):

Methylenetetrahydrofolate reductase gene C677T and A1298C polymorphisms in patients with small cell and non-small cell lung cancer. Oncol. Rep. Sep-Oct., 10(5): 1341-1344.

18- Mtiraoui N, Ezzidi I, Chaieb M, Marmouche H, Aouni Z, Chaieb A, Mahjoub T, Vaxillaire M, Almawi WY.(2007):MTHFR C677T and A1298C gene polymorphisms and hyperhomocysteinemia as risk factors of diabetic nephropathy in type 2 diabetes patients. Diabetes Res.Clin.Pract. Jan.,75(1):99-106.

19-Moczulski D, Fojcik H, ZukowskaSzczechowska E, Szydlowska I, Grzeszczak W(2003): Effects of the C677T and A1298C polymorphisms of the MTHFR gene on the genetic predisposition for diabetic nephropathy. Nephrol Dial Transplant., Aug;18(8):1535-1540.

20-Broughton PipkinF(1995): The hypertensive disorders of pregnancy. BMJ., 311: 609-613.

21-Chesley LC, Annito JC, Cosgrove RA (1968): The familial factor in toxaemia of pregnancy. Obstet. Gynaecol. 32: 303-311.

22- Roberts JM, Taylor RN, Musci TJ, Rodgers GM, Hubel CA, McLaughlin MK (1989): Preeclampsia: an endothelial cell disorder. Am. J. Obstet. Gynecol., 161: 1200-1204.

23-Dekker G, de Vries JIP, Doelitzsch PM, HuiJgens PC, Von Blomberg BME, Jacobs C (1995): Underling disorders associated with severe early-onset preeclampsia. Am. J. Obstet. Gynecol., 173: 1042-1048.

24- $\quad$ Girling J, de Swiet M (1998): Inherited thrombophilia and pregnancy. Curr.Opin.ObstetGynecol., 10: 135-144.

25-Vorga EA, Sturm AC, Misita CP, Moll S (2005): Cardiology patient pages. Homocysteine and MTHFR mutations: relation to thrombosis and coronary artery disease. Circulation, 17; 111(19): 289-293.

26-Almawi WY, Finan RR, Tamim H, Daccache $J L$, Irani-Hakime $N$ (2004b): Differences in the frequency of the C677T mutation in the methylenetetrahydrofolate reductase (MTHFR) 
gene among the Lebanese population. American Journal of Hematology, 76: 85-87.

27-Nelen WL, Blom HJ, Thomas CM, Steegers EA, Boers GH, Eskes TK (1998): Methylenetetrahydrofolate reductase polymorphism affects the change in homocysteine and folate concentrations resulting from low dose folic acid supplementation in women with unexplained recurrent miscarriages. Journal of Nutrition, 128: 1336-1341.

28- Lissak A, Sharon A, Fruchter O, Kassel A, Sanderovitz J, Abramovici H (1999): Polymorphism for mutation of cytosine to thymine at location 677 in the methylenetetrahydrofolate reductase gene is associated with recurrent early fetal loss. American Journal of Obstetrics and Gynecology, 181: 126-130.

29-Unfried G, Griesmacher A, Weismuller W, Nagele F, Huber JC, TempferCB(2002): The C667T polymorphism of the methylenetetrahydrofolate reductase gene and idiopatheic recurrent miscarriage. Obstetrics.Gynecology, 99: 614-619.

30- Nelen WL, Steegers EA, Eskes TK, Blom HJ (1997): Genetic risk factor for unexplained recurrent early pregnancy loss. Lancet., 350: 861.

31-Gerhardt A, Scharf RE, Beckmann MW, Struve S, Bender HG, Pillny M, Sandmann W, Zotz RB (2000): Prothrombin and factor V mutations in women with a history of thrombosis during pregnancy and the puerperium. N. Engl. J. Med., 342: 374-380.

32-Stamatian F, Caracostea G, Muresan D, Bartok I, Militaru M, Procopciuc L, Popp R, Trifa $A$ (2009): The evaluation ofinherited thrombophilic conditions in patients with bleeding in the first trimester of pregnancy. MVH. Bio flux., 1(1): 9-17.

33-Van der Molen EF, Areds GE, Nelen WL, Van der Put NJ, Heil SG, Eskes TK (2000): A common mutation in the 5,10methylenetetrahydrofolate reductase gene as a new risk factor for placental vasculopathy. American Journal of Obstetrics and Gynecology, 182: 12581263.

34-Lachmeijer AM, Arngrimsson R, Bastiaans EJ, Pals G, ten Kate LP, de Vries JI, Kostens PJ, Aarnoudse JG, Dekker GA (2001): Mutations in the gene for methylenetetrahydrofolate reductase, homocysteine levels, and vitamin status in women with a history of preeclampsia. American Journal of Obstetrics and Gynecology, 184: 394-402.

35- Murakami S, Matsubara N, Saitoh M, Miyakaw S, Shoji M, Kubo T (2001): The relation between plasma homocysteine concentration and methylenetetrahydrofolate reductase gene polymorphism in pregnant women. Journal of Obstetrics and Gynaecology, Research 27: 349352.

36- Quere I, Bellet H, Hoffet M, Janbon C, Mares P, Gris JC (1998): A woman with five consecutive fetal death: case report and retrospective analysis of hyperhomocysteinemia prevalence in 100 consecutive women with recurrent miscarriages. Fertility and Sterility, 69: 152-154.

37- $\quad$ Sarig G, Younis JS, Hoffman R, Lanir $N$, Blumenfeld $Z, \quad B r e n n e r \quad B \quad$ (2002): Thrombophilia is common in women with idiopathic pregnancy loss and is associated with late pregnancy wastage. Fertility and Sterility, 77: 342-347.

38-Said JM, Higgins JR, Moses EK, Walker SP, Borg AJ, Monagle PT, Brennecke SP (2010): Inherited thrombophilia polymorphisms and pregnancy outcomes in nulliparous women. Obstet. Gynecol., 115(1): 5-13.

39-Sacchi E, Tagliabue L, Duca F, Mannucci PM (1997): High frequency of the C677T mutation in the methylenetetrahydrofolate reductase (MTHFR) gene in Northern Italy. Thrombosis and Haemostasis, 78: 963-964.

40-Almawi WY, Ameen G, Tamim H, Finan RR, Irani-Hakime N (2004a):Factor V G1691A, prothrombin G20210A, and methylenetetrahydrofolate reductase [MTHFR] C677T gene polymorphism in angiographically documented coronary artery disease. Journal of Thrombosis and Thrombolysis, 17: 199-205.

41-Gris JC, Quere I, Monpeyroux F, Mercier E, Ripart-Neveu S, Tailland ML, Hoffet M, Berlan J, Daures JP, Mares P (1999): Case-control study of the frequency of thrombophilic disorders in couples with late foetal loss and no thrombotic antecedent-the Nimes Obstetricians and Haematologists Study5 (NOHA5). Thromb.Haemost., 81: 891-899.

42- Zhang J (2007): Partner change, birth interval and risk of pre-eclampsia: a paradoxical triangle. Paediatric and Perinatal Epidemiology, 21 (Suppl 1): 31-35. 